\title{
Metabolism of Vitamin D
}

\author{
A NEW CHOLECALCIFEROL METABOLITE, INVOLVING LOSS OF \\ HYDROGEN AT C-1, IN CHICK INTESTINAL NUCLEI
}

\author{
By D. E. M. LAWSON, P. W. WILSON AND E. KODICEK \\ Dunn Nutritional Laboratory, University of Cambridge and Medical Research Council, \\ Cambridge CB4 $1 X J$
}

(Received 16 June 1969)

\begin{abstract}
1. A comparison was made of the nature and intestinal intracellular distribution of the metabolites formed in vitamin $\mathrm{D}$-deficient chicks from $\left[4^{-14} \mathrm{C}\right]$ cholecalciferol and $\left[1^{-3} \mathrm{H}\right]$ cholecalciferol. 2. The simultaneous administration of the two radioactive substances showed the presence in blood, liver, intestine, kidney and bone of cholecalciferol, its ester, 25-hydroxycholecalciferol and a further metabolite of cholecalciferol more polar than 25 -hydroxycholecalciferol. The ${ }^{3} \mathrm{H} /{ }^{14} \mathrm{C}$ ratios in these four radioactive components were the same as that of the dosed material $(4 \cdot 7: 1)$ with the exception of the most polar material. The ${ }^{3} \mathrm{H} /{ }^{14} \mathrm{C}$ ratio was lower in the fourth, most polar, metabolite $(0 \cdot 4: 1-1 \cdot 8: 1)$ in all tissues examined, with the exception of blood. 3. In the chick intestine the polar metabolite accounted for almost $70 \%$ of the radioactivity in this tissue after a dose of $0.5 \mu \mathrm{g}$. of $\left[4{ }^{14} \mathrm{C}, 1 .{ }^{3} \mathrm{H}\right]$ cholecalciferol. This polar metabolite from the intestine also had the lowest ${ }^{3} \mathrm{H} /{ }^{14} \mathrm{C}$ ratio of all the tissues. It appears that in the chick intestine the polar metabolite reaches a maximum concentration of $1 \mathrm{ng}$./g. of tissue, above which it cannot be increased irrespective of the dose of the vitamin. 4. The intestinal intracellular organelle with the highest concentration of ${ }^{14} \mathrm{C}$ radioactivity is the nucleus, and this radioactivity is almost entirely due to the polar metabolite with the lowered ${ }^{3} \mathrm{H} /{ }^{4} \mathrm{C}$ ratio, in this case $<0 \cdot 2: 1$. It appears to be further localized in the chromatin of the nuclei. However, about half of the polar metabolite in the intestine is extranuclear. 5. Double-labelled 25-hydroxycholecalciferol was prepared and after its administration to vitamin D-deficient chicks the polar metabolite with the lowered ${ }^{3} \mathrm{H} /{ }^{14} \mathrm{C}$ ratio was detected in liver, kidney, intestine, bone, muscle and heart. 6. None of the polar metabolite with the lowered ${ }^{3} \mathrm{H} /{ }^{14} \mathrm{C}$ ratio was detected $16 \mathrm{hr}$. after dosing with either the double-labelled vitamin or the double-labelled 25hydroxycholecalciferol in blood and adipose tissue of vitamin D-deficient chicks, nor in the intestine, liver and kidney of supplemented birds. 7. The reasons for this loss of ${ }^{3} \mathrm{H}$ relative to ${ }^{14} \mathrm{C}$ are discussed in relation to possible chemical structures of this new polar metabolite.
\end{abstract}

The use of radioactively labelled ergocalciferol and cholecalciferol has proved valuable in the study of the metabolism of vitamin $D$. The first studies were made with [U-14C]ergocalciferol prepared biosynthetically from [1-14C]acetate by Saccharomyces cerevisiae (Kodicek, 1955). Later Norman \& DeLuca (1963) prepared $\left[\mathrm{G}-{ }^{3} \mathrm{H}\right]$ cholecalciferol of high specific radioactivity $(7 \cdot 2 \mathrm{mc} / \mathrm{m}-\mathrm{mole})$ and Callow, Kodicek \& Thompson (1966) showed that after a dose of such material, $4 \%$ of the ${ }^{3} \mathrm{H}$ appeared within $24 \mathrm{hr}$. in the water of the expired air. They also prepared a number of tritiated vitamins $D$, namely $\left[24,25,26,27-{ }^{3} \mathrm{H}_{9}\right]-,\left[{ }^{3}-{ }^{3} \mathrm{H}\right]-,\left[6-{ }^{3} \mathrm{H}\right]-$, [3- $\left.{ }^{3} \mathrm{H}\right]-$ and $\left[1 \alpha-{ }^{3} \mathrm{H}\right]$-cholecalciferol, and showed that the expired air of the rats dosed with $\left[1 \alpha^{-3} \mathbf{H}\right]$ cholecalciferol contained the lowest amount of radioactivity. Therefore $\left[1 \alpha-{ }^{3} \mathrm{H}\right]$ cholecalciferol of specific radioactivity $141 \mathrm{mc} / \mathrm{m}$-mole has been used in this laboratory in a series of studies of vitamin $D$ metabolism (Fraser \& Kodicek, 1965, 1966, 1968, 1969; Bell \& Kodicek, 1967). Neville \& DeLuca (1966) prepared $\left[1,2-{ }^{3} \mathrm{H}\right]$ cholecalciferol of specific radioactivity $180 \mathrm{mc} / \mathrm{m}$-mole and showed the existence of another biologically active metabolite of vitamin D, originally designated Peak IV (Norman, Lund \& DeLuca, 1964), in rats. The biologically active component of Peak IV, in rats and pigs, has been identified as 25-hydroxycholecalciferol (Blunt, 
DeLuca \& Schnoes, 1968), which had biological activity about $40 \%$ greater than that of the parent vitamin (Blunt, Tanaka \& DeLuca, 1968).

Studies on the subcellular distribution of vitamin D with relatively large amounts of the labelled vitamin did not suggest a specific site of localization (Kodicek, 1963; Norman \& DeLuca, 1964). However, Haussler \& Norman (1967) and Stohs \& DeLuca (1967) found, with doses of the order of $1 \mu \mathrm{g}$. of either $\left[{ }^{4-14} \mathrm{C}\right]-$ or $\left[1,2-{ }^{3} \mathrm{H}\right]$-cholecalciferol, that the nuclear fraction of mucosal cells from both chick and rat had the highest proportion of the intestinal radioactivity. In the rat the nuclear radioactivity was characterized by its chromatographic properties (Stohs \& DeLuca, 1967) as corresponding to the Peak IV material described by Norman et al. (1964). However, Haussler, Myrtle \& Norman (1968) showed that the chick intestinal nuclear radioactivity could be fractionated into three substances (4a, $4 \mathrm{~b}$ and $4 \mathrm{c}$ ), of which only one (4b) was found in the nuclear chromatin. They were not able to state which of the three substances was 25 -hydroxycholecalciferol.

We have also found (Wilson, Lawson \& Kodicek, 1967) that a fraction of the intestinal cell containing nuclei and brush borders had the highest concentration of radioactivity after a large dose of $\left[1 \alpha^{-3} \mathrm{H}\right]$ cholecalciferol. In the present study we were unable to find radioactivity localized in intestinal nuclei after a dose of $0 \cdot 25 \mu \mathrm{g}$. of $\left[1 \alpha^{-3} \mathrm{H}\right]$. cholecalciferol. Having developed a method for preparing nuclei in adequate yields and of accepted purity (Lawson, Wilson, Barker \& Kodicek, 1969 $a$ ), we investigated the nature and localization of the metabolites of vitamin $D$ by using $\left[4{ }^{14} \mathrm{C}, 1 \alpha^{-3} \mathrm{H}\right]$ cholecalciferol. These experiments have shown that there is in chick intestinal nuclei a metabolite of vitamin $\mathrm{D}$, more polar than 25 -hydroxycholecalciferol, that has lost its ${ }^{3} \mathrm{H}$ from position $\mathrm{C}-1$. These studies were extended to other tissues and a preliminary report of this work has been published (Lawson, Wilson \& Kodicek, 1969b).

\section{EXPERIMENTAL}

Animals. Rhode Island Red X Light Sussex chicks (1 day old) were obtained from the National Institute for Research in Dairying (Shinfield, Reading). They were fed on the diet and supplements as described previously (Lawson et al. 1969a), and were used after 4 weeks, when they were vitamin D-deficient. The dosing material was administered intracardially in propylene glycol $16 \mathrm{hr}$. before the chicks were killed, unless otherwise stated. In all experiments the animals were starved overnight before being killed. The tissues were removed from the birds in a cold-room at $4^{\circ}$, and then either washed in cold $0.9 \% \mathrm{NaCl}$ before tissue fractionation or immediately frozen with liquid $\mathrm{N}_{2}$ for determinations on the whole tissue.

Tissue fractionation. The mitochondrial, microsomal and cytoplasmic fractions were obtained by a modified method of Schneider \& Hogeboom (1950) as previously described (Wilson et al. 1967). The nuclear-debris fraction and the pure nuclei were prepared as described in the preceding paper under method (b) (Lawson et al. 1969a). The supernatant from the first $800 \mathrm{~g}$ centrifugation, containing the mitochondria, microsomes and cytoplasm, was frequently analysed without further fractionation and is referred to as the supernatant fraction. Purified chromatin was prepared by the method of Haussler et al. (1968) from the nucleardebris fraction.

Extraction of intracellular fractions and tissues. Suspensions of intracellular fractions and of tissues were extracted with chloroform-methanol by the method of Bligh \& Dyer (1959), and the lipids in the chloroform phase were taken for chromatography or radioactivity measurements. All procedures were carried out at $4^{\circ}$ and final fractions were kept under $\mathrm{N}_{2}$. Tissues were blended with $0.9 \%$ $\mathrm{NaCl}$ in an MSE model $\mathbf{7 7 0 0}$ homogenizer and extracted with chloroform-methanol as described above.

Column chromatography. Lipid samples were usually chromatographed on a column $(50 \mathrm{~cm} . \times 1.5 \mathrm{~cm}$.) of silica gel M.F.C. (Hopkin and Williams, Chadwell Heath, Essex) deactivated with $10 \%(\mathrm{v} / \mathrm{w})$ of water. Elution was carried out with a continuous gradient of light petroleum (b.p. $\left.40-60^{\circ}\right)$ to diethyl ether $(800 \mathrm{ml}$.), then $300 \mathrm{ml}$. of diethyl ether, and finally a gradient of diethyl ether to methanol $\left(400 \mathrm{ml}\right.$.). The column temperature was maintained at $4^{\circ}$. Fractions $(10 \mathrm{ml}$.) were collected for radioactivity assay and u.v.-absorption measurement.

In some instances a short column $(10 \mathrm{~cm} . \times 1 \mathrm{~cm}$.) of untreated silica gel M.F.C. was used for small samples of lipid extracts. Eluting solvents were successive $50 \mathrm{ml}$. portions of $5 \%(\mathrm{v} / \mathrm{v})$ diethyl ether in light petroleum (fractions $A$ and $B$ ), $50 \%(\mathrm{v} / \mathrm{v})$ diethyl ether in light petroleum (fractions $C$ and $D$ ), $75 \%(\mathrm{v} / \mathrm{v})$ diethyl ether in light petroleum (fraction $E$ ), diethyl ether (fractions $F$ and $G$ ) and $5 \%(\mathrm{v} / \mathrm{v})$ methanol in diethyl ether (fractions $H$ and $I$ ). Authentic samples of cholecalciferol and 25-hydroxycholecalciferol were co-chromatographed on both systems to establish the identity of a particular radioactive peak.

Materials. $\left[1 \alpha^{-3} \mathrm{H}\right]$ Cholecalciferol (sp. radioactivity $141 \mathrm{mc} / \mathrm{m}$-mole; 720000 d.p.m. $/ \mu \mathrm{g}$.) and unlabelled 25hydroxycholecalciferol were prepared by Dr P. A. Bell of this laboratory. $\left[4^{14} \mathrm{C}\right] \mathrm{Cholecalciferol}$ (sp. radioactivity $19 \cdot 2 \mathrm{mc} / \mathrm{m}$-mole; 110000 d.p.m./ $\mathrm{gg}$.) was obtained from Phillips-Duphar, Amsterdam, The Netherlands.

The 25-hydroxy $\left[4{ }^{14} \mathrm{C}, 1-{ }^{3} \mathrm{H}\right]$ cholecalciferol was isolated from the blood of vitamin D-deficient chicks $16 \mathrm{hr}$. after a $25 \mu \mathrm{g}$. dose of double-labelled cholecalciferol. The blood was extracted with chloroform-methanol and the lipid from the chloroform phase was chromatographed on a silica gel M.F.C. column $\left(50 \mathrm{~cm} . \times 1 \cdot 5 \mathrm{~cm}\right.$.) at $4^{\circ}$ as described above. The 25-hydroxycholecalciferol fraction was collected and the ${ }^{3} \mathrm{H} /{ }^{14} \mathrm{C}$ radioactivity (total d.p.m.) ratio calculated and found to be $4 \cdot 4: 1$. This was given to the chicks intracardially in $0.2 \mathrm{ml}$. of propylene glycol, the amount of the dose being calculated by assuming the specific radioactivity to be the same as that of the original $\left[4-{ }^{14} \mathrm{C}\right]$ cholecalciferol.

Chemical determinations. These were performed as described in the preceding paper (Lawson et al. 1969a).

Measurement of radioactivity. Lipid samples from chloroform-methanol extractions were assayed in a Packard Tri-Carb automatic liquid scintillation spectrometer no. 
3375, with the counting solution described previously (Wilson et al. 1967). Quenching was corrected for by using the automatic external standardization and correlation curves for ${ }^{14} \mathrm{C}$ and ${ }^{3} \mathrm{H}$, either individually or combined.

\section{RESULTS}

The intracellular distribution of radioactivity after a $1 \mu \mathrm{g}$. dose of $\left[1-{ }^{3} \mathrm{H}\right]$ cholecalciferol is shown in Table 1. The specific radioactivity in the nuclei was less than that in the homogenate, and this cell fraction contained the lowest proportion of total intestinal radioactivity. Although the nucleardebris pellet obtained from the homogenate after centrifuging at $800 \mathrm{~g}$ for $10 \mathrm{~min}$. contained $46 \%$ of the radioactivity, a further three successive washings removed about one-third of this radioactivity. After the final purification stage involving the sedimentation of the nuclei through $2.4 \mathrm{M}$ sucrose, only about $8 \%$ of the remaining radioactivity was recovered in the pellet. As shown in the preceding paper (Lawson et al. 1969a), this failure to find radioactivity in the nuclei was not due to damage of this organelle.

A series of experiments was then carried out to compare the proportion of radioactivity found in isolated nuclei from chicks dosed with various amounts of either $\left[4^{-14} \mathrm{C}\right]-$ or $\left[1-{ }^{3} \mathrm{H}\right]$-cholecalciferol (Table 2). Irrespective of the dose of $[1-3 \mathrm{H}]-$ cholecalciferol, at least in the range $0 \cdot 25-2 \cdot 0 \mu \mathrm{g}$., the proportion of intestinal radioactivity in the nuclei was low. However, in agreement with Haussler \& Norman (1967), with [4-14C]cholecalciferol the proportion of radioactivity in the nuclei rose from $18 \%$ to $45 \%$ as the dose decreased from 1.0 to $0.5 \mu \mathrm{g}$.

Table 3 shows the proportion of a dose of the double-labelled cholecalciferol $\left({ }^{3} \mathrm{H} /{ }^{14} \mathrm{C}\right.$ ratio $\left.4 \cdot 7: 1\right)$ recovered in the various tissues of vitamin $D$.

Table 1. Intracellular distribution of radioactivity in the chick intestine after a dose of $\left[1 .{ }^{3} \mathrm{H}\right]$ cholecalciferol

Vitamin D-deficient chicks were given a $1 \mu \mathrm{g}$. dose of $\left[1{ }^{3} \mathrm{H}\right]$ cholecalciferol and killed after $16 \mathrm{hr}$. Results are expressed as percentages of the dose recovered in the homogenate and also as specific radioactivity (d.p.m./mg. of $\mathrm{N}$ ).

$\begin{array}{ccc}\text { Homogenate A } & \begin{array}{c}\text { Distribution } \\ \left(\% \text { of }{ }^{3} \mathrm{H}\right)\end{array} & \begin{array}{c}\text { Sp. radioactivity } \\ \text { Mitochondrial }\end{array} \\ \text { Microsomal } & 28 \cdot 4 & 15 \cdot 0 \\ \text { Cytoplasmic } & 12 \cdot 8 & 45 \cdot 5 \\ \text { Nuclear debris } & \mathbf{1 2 \cdot 7} & 26 \cdot 0 \\ \text { Homogenate B } & - & 7 \cdot 0 \\ \text { Nuclei } & 8 \cdot 2^{*} & 22 \cdot 0 \\ \end{array}$

* Corrected for recovery of DNA (see Lawson et al. 1969a). deficient chicks. In all tissues, except the blood, less ${ }^{3} \mathrm{H}$ was recovered than ${ }^{14} \mathrm{C}$.

The chromatograms of blood (Fig. 1), kidney and the intestinal supernatant-fraction lipids on silicagel columns (see Lawson et al. 1969b) showed four peaks of ${ }^{14} \mathrm{C}$ radioactivity, which were identified as being primarily due to cholecalciferol ester, cholecalciferol, 25-hydroxycholecalciferol and an unidentified metabolite (peak $P$ ). In addition to these, the liver extracts contained a fifth peak of radioactivity (peak $U$ ). The peak $P$ in the blood chromatogram differed significantly from that in the kidney, liver and intestinal supernatant fraction in its ${ }^{3} \mathbf{H}$ radioactivity, and ${ }^{3} \mathbf{H} /{ }^{14} \mathrm{C}$ ratio (Table 4). Cholecalciferol, its ester and 25-hydroxycholecalciferol showed ratios greater than $3 \cdot 8: 1$, usually $4 \cdot 3: 1-4 \cdot 5: 1$. On the other hand the ${ }^{3} \mathrm{H} /{ }^{14} \mathrm{C}$ ratio in peak $P$ varied from $4 \cdot 7: 1$ in the blood down

Table 2. Radioactivity in the chick intestinalmucosal homogenate and isolated nuclei after a dose of either $\left[4-{ }^{14} \mathrm{C}\right]-$ or $\left[1-{ }^{3} \mathrm{H}\right]$-cholecalciferol

Vitamin D-deficient chicks were given a dose of labelled cholecalciferol and killed $16 \mathrm{hr}$. later. Results are expressed for homogenates as percentages of the dose and for the isolated nuclei as percentages of the total radioactivity in the homogenate, with correction for the recovery of nuclei.

\begin{tabular}{|c|c|c|c|c|}
\hline \multirow{2}{*}{$\begin{array}{l}\text { Dose } \\
(\mu \mathrm{g} .)\end{array}$} & \multicolumn{2}{|c|}{ Distribution $\left(\%\right.$ of $\left.{ }^{14} \mathrm{C}\right)$} & \multicolumn{2}{|c|}{ Distribution $\left(\%\right.$ of $\left.{ }^{3} \mathrm{H}\right)$} \\
\hline & Homogenate & Nuclei & Homogenate & Nuclei \\
\hline 2 & - & - & $1 \cdot 4$ & 5 \\
\hline 1 & $1 \cdot 1$ & 18 & 0.4 & 9 \\
\hline 0.5 & $1 \cdot 4$ & 45 & $0 \cdot 3$ & 6 \\
\hline $0 \cdot 25$ & - & - & $0 \cdot 4$ & 2 \\
\hline
\end{tabular}

Table 3. Distribution of radioactivity in lipid extracts of chick tissues after a dose of $\left[4-{ }^{14} \mathrm{C}, 1-{ }^{3} \mathrm{H}\right]-$ cholecalciferol

Vitamin D-deficient chicks (18) were each given $0.5 \mu \mathrm{g}$. of the double-labelled vitamin $\left({ }^{3} \mathrm{H} /{ }^{14} \mathrm{C}\right.$ ratio $\left.4 \cdot 7: 1\right)$ and the tissues removed after death $16 \mathrm{hr}$. later. The results are expressed as percentages of the dose $/ \mathrm{ml}$. or $\mathrm{g}$. of fresh tissue.

$\begin{array}{llll}\text { Blood } & 0.99 & 0.93 & 4 \cdot 5 \\ \text { Liver } & 0 \cdot 43 & 0 \cdot 19 & 2 \cdot 1 \\ \text { Kidney } & 0 \cdot 36 & 0 \cdot 22 & 3 \cdot 4 \\ \text { Intestinal mucosa } & 0 \cdot 31 & 0.07 & 1.0 \\ \quad \begin{array}{l}\text { Supernatant fraction } \\ \quad \text { Nuclear debris }\end{array} & 0 \cdot 19 & 0.05 & 1.4 \\ \begin{array}{l}\text { Bones (tibia and } \\ \text { fibula) }\end{array} & 0.08 & 0.02 & 0.9 \\ & 0 \cdot 12 & 0.09 & 3.8\end{array}$




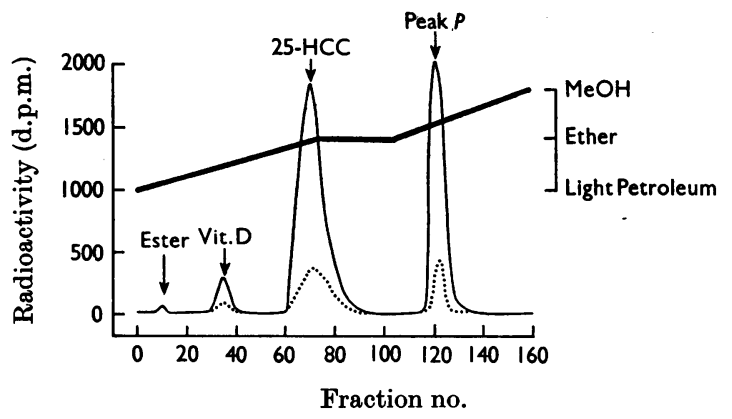

Fig. 1. Gradient-elution chromatography of the lipid extract of the blood of vitamin D-deficient chicks after a dose of $0.5 \mu \mathrm{g}$. of $\left[4 .{ }^{14} \mathrm{C}, 1.3 \mathrm{H}\right]$ cholecalciferol $16 \mathrm{hr}$. before death.,$-{ }^{3} \mathrm{H}$ radioactivity; $\cdots,{ }^{14} \mathrm{C}$ radioactivity. Vit. D, cholecalciferol; 25-HCC, 25-hydroxycholecalciferol.

to $0.4: 1$ in the intestinal mucosa. Peak $U$, found only in the liver, had a ${ }^{3} \mathrm{H} /{ }^{14} \mathrm{C}$ ratio of $2 \cdot 6: 1$, but this material was not investigated further. In Table 5 the ${ }^{3} \mathrm{H} /{ }^{14} \mathrm{C}$ ratios are shown for subcellular fractions of intestine and kidney. The intestinal supernatant fraction had a significantly decreased ratio of $0 \cdot 5: 1$. The peak $P$ fraction of intestinal nuclei contained $97 \%$ of the radioactivity and the ${ }^{3} \mathrm{H} /{ }^{14} \mathrm{C}$ ratio was less than $0 \cdot 2: 1$. The cholecalciferol area of the chromatogram contained less than $3 \%$ of the radioactivity, and 25-hydroxycholecalciferol could not be detected at all (Fig. 2). The kidney nuclear-debris fraction gave results similar to those observed in the corresponding intestinal fraction.

Thus it became apparent that the metabolite of vitamin $\mathrm{D}$ in the nuclei studied has lost its ${ }^{3} \mathbf{H}$ from C-1, thereby accounting for our failure to find ${ }^{3} \mathrm{H}$ in the nuclei after dosing with $\left[1 \alpha^{-3} \mathrm{H}\right]$ cholecalciferol. Although this substance seems to be concentrated in the intestinal nuclei, a proportion of the radioactivity appears to be extranuclear. In contrast, peak $\mathrm{P}$ in the blood has a normal ${ }^{3} \mathrm{H} /{ }^{14} \mathrm{C}$ ratio $(4 \cdot 7: 1)$ and thus it seems that the ${ }^{3} \mathrm{H}$-deficient metabolite is not present in this tissue, at least at $16 \mathrm{hr}$. after dosing. In vitamin $\mathrm{D}$-supplemented birds a dose of double-labelled cholecalciferol appeared to give results (Table 6) similar to those obtained with vitamin D-deficient birds. However, chromatographic analysis of the lipid extracts revealed a significant difference in that peak $P$ was barely detectable (Table 7). Further, in the peak $P$ area of the chromatogram the ${ }^{3} \mathrm{H} /{ }^{14} \mathrm{C}$ ratio in liver and kidney was almost unchanged and in the intestinal nuclear-debris fraction no ${ }^{14} \mathrm{C}$ radioactivity could be detected. Most of the radioactivity in all tissues examined was found in the cholecalciferol region of the chromatograms.

Time-course of appearance of peak $\mathrm{P}$. Ten vitamin

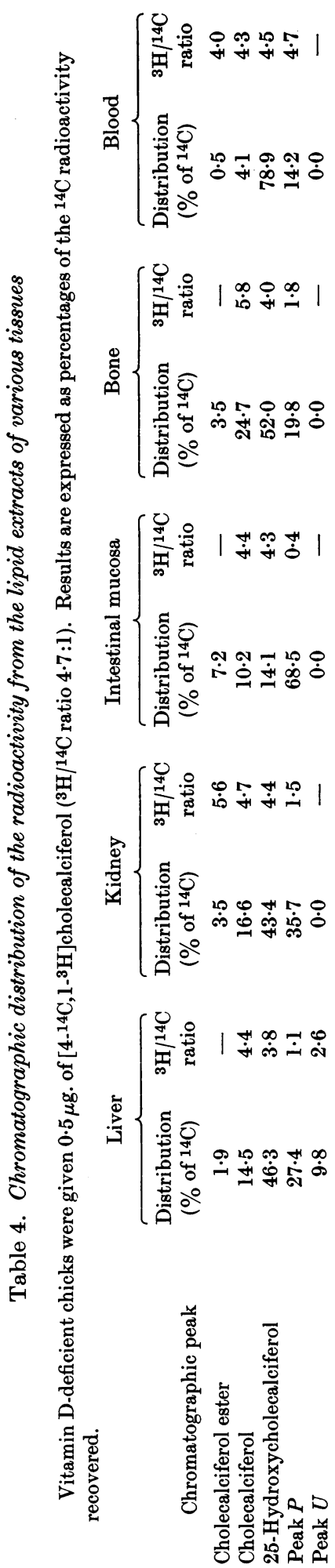


Table 5. Chromatographic distribution of the radioactivity from the lipid extracts of intestinal and kidney cell fractions

Vitamin D-deficient chicks were given $0 \cdot 5 \mu \mathrm{g}$. of $\left[4-{ }^{14} \mathrm{C}, 1-{ }^{3} \mathrm{H}\right]$ cholecalciferol $\left({ }^{3} \mathrm{H} /{ }^{14} \mathrm{C}\right.$ ratio $\left.4 \cdot 7: 1\right)$. The cell fractions of the mucosa were obtained from birds killed $16 \mathrm{hr}$. after dosing, and those of the kidney, $8 \mathrm{hr}$. after dosing. Results are expressed as percentages of the ${ }^{14} \mathrm{C}$ radioactivity recovered.

\begin{tabular}{|c|c|c|c|c|c|c|c|c|}
\hline \multirow[b]{3}{*}{$\begin{array}{l}\text { Chromato- } \\
\text { graphic peak }\end{array}$} & \multicolumn{6}{|c|}{ Intestinal mucosa } & \multirow{2}{*}{\multicolumn{2}{|c|}{$\underbrace{\text { Kidney }}_{\text {Nuclear debris }}$}} \\
\hline & \multicolumn{2}{|c|}{ Supernatant fraction } & \multicolumn{2}{|c|}{ Nuclear debris } & \multicolumn{2}{|c|}{ Nuclei } & & \\
\hline & $\begin{array}{c}\text { Distribution } \\
\left(\% \text { of }{ }^{14} \mathrm{C}\right)\end{array}$ & $\begin{array}{c}{ }^{3} \mathrm{H} /{ }^{14} \mathrm{C} \\
\text { ratio }\end{array}$ & $\begin{array}{c}\text { Distribution } \\
\left(\% \text { of }{ }^{14} \mathrm{C}\right)\end{array}$ & $\begin{array}{c}{ }^{3} \mathrm{H} /{ }^{14} \mathrm{C} \\
\text { ratio }\end{array}$ & $\begin{array}{c}\text { Distribution } \\
\left(\% \text { of }{ }^{14} \mathrm{C}\right)\end{array}$ & $\begin{array}{c}{ }^{3} \mathrm{H} /{ }^{14} \mathrm{C} \\
\text { ratio }\end{array}$ & $\begin{array}{c}\text { Distribution } \\
\left(\% \text { of }{ }^{14} \mathrm{C}\right)\end{array}$ & $\begin{array}{c}{ }^{3} \mathrm{H} /{ }^{14} \mathrm{C} \\
\text { ratio }\end{array}$ \\
\hline $\begin{array}{l}\text { Cholecalciferol } \\
\text { ester }\end{array}$ & 0.8 & $4 \cdot 0$ & 3.4 & - & $0 \cdot 0$ & - & $10 \cdot 6$ & - \\
\hline Cholecalciferol & $6 \cdot 1$ & $4 \cdot 4$ & $10 \cdot 2$ & - & $2 \cdot 7$ & 一 & $58 \cdot 1$ & $4 \cdot 3$ \\
\hline $\begin{array}{l}\text { 25-Hydroxy- } \\
\text { cholecalciferol }\end{array}$ & $20 \cdot 7$ & $4 \cdot 5$ & $10 \cdot 5$ & - & $0 \cdot 0$ & - & $7 \cdot 8$ & 一 \\
\hline Peak $P$ & $68 \cdot 0$ & 0.5 & $71 \cdot 8$ & $0 \cdot 8$ & $97 \cdot 3$ & $<0.2$ & $23 \cdot 5$ & $0 \cdot 4$ \\
\hline
\end{tabular}

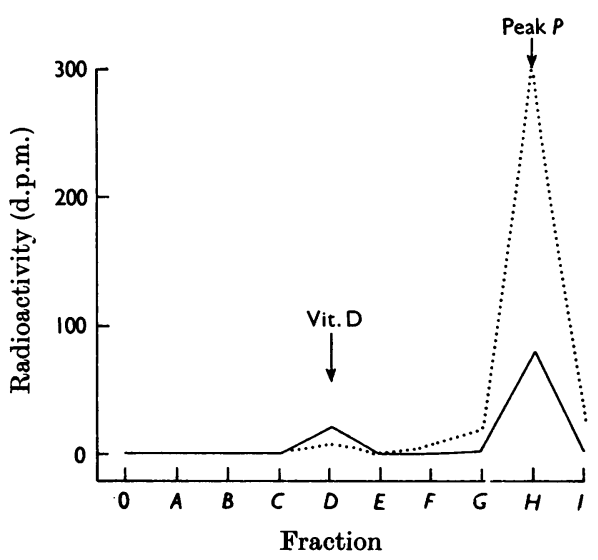

Fig. 2. Batch-elution chromatography of the lipid extract of the purified intestinal nuclei from vitamin D-deficient chicks after a dose of $0.5 \mu \mathrm{g}$. of $\left[4 .{ }^{14} \mathrm{C}, 1.3 \mathrm{H}\right]$ cholecalciferol $16 \mathrm{hr}$. before death. $\longrightarrow,{ }^{3} \mathrm{H}$ radioactivity; $\cdots,{ }^{14} \mathrm{C}$ radioactivity. Vit. D, cholecalciferol.

D-deficient birds each received $0 \cdot 5 \mu \mathrm{g}$. of $[4-14 \mathrm{C}, 1-$ ${ }^{3} \mathrm{H}$ ]cholecalciferol and were killed in pairs after $\frac{1}{2}$, 2, 4, 8 and $16 \mathrm{hr}$. An intestinal nuclear-debris fraction was prepared and the lipids from this fraction and from blood were chromatographed on silica gel with batch elution (Fig. 3).

At $\frac{1}{2} \mathrm{hr}$. the cholecalciferol accounted for the major proportion of the radioactivity in the blood and the nuclear-debris fraction, but it declined in amount rapidly in both tissues up to $8 \mathrm{hr}$. and kept decreasing until $16 \mathrm{hr}$. in blood. Although not shown in these graphs, the cholecalciferol ester followed a similar pattern. In the nuclear-debris fraction the concentration of cholecalciferol reached a peak between 2 and $4 \mathrm{hr}$., whereas the ester reached its maximum concentration at about $8 \mathrm{hr}$.
Table 6. Distribution of radioactivity after a dose of $\left[4^{-14} \mathrm{C}, 1-{ }^{3} \mathrm{H}\right]$ cholecalciferol to vitamin D-supplemented birds

Two vitamin D-deficient chicks were each supplemented with a total of $20 \mu \mathrm{g}$. of cholecalciferol over the previous 4 days before a $0.5 \mu \mathrm{g}$. dose of $\left[4^{-14} \mathrm{C}, 1-3 \mathrm{H}\right]$ cholecalciferol. They were killed $16 \mathrm{hr}$. later. Results are expressed as percentages of the dose/g. of original fresh tissue.

\begin{tabular}{|c|c|c|c|}
\hline & \multicolumn{2}{|c|}{ Distribution } & \multirow{2}{*}{$\begin{array}{c}{ }^{3} \mathrm{H} /{ }^{14} \mathrm{C} \\
\text { ratio }\end{array}$} \\
\hline & $\left(\%\right.$ of $\left.{ }^{14} \mathrm{C}\right)$ & $\left(\%\right.$ of $\left.{ }^{3} \mathrm{H}\right)$ & \\
\hline Liver & $1 \cdot 13$ & $0 \cdot 80$ & $3 \cdot 4$ \\
\hline Kidney & 0.42 & $0 \cdot 32$ & $3 \cdot 6$ \\
\hline \multicolumn{4}{|l|}{ Intestinal mucosa } \\
\hline Supernatant fraction & 0.05 & 0.02 & - \\
\hline Nuclear debris & 0.04 & 0.02 & - \\
\hline
\end{tabular}

This pattern is similar to that reported in rat intestine (Fraser \& Kodicek, 1968).

The 25-hydroxycholecalciferol fraction continued to increase in amount in blood up to $16 \mathrm{hr}$. when it accounted for $\mathbf{7 0} \%$ of the total radioactivity. In the intestinal nuclear-debris fraction, however, it never accounted for more than $7 \%$ of the radioactivity in this fraction. The chromatograms of the blood radioactivity showed a small peak $P$, which accounted for about $14 \%$ of the total radioactivity. However, only at $4 \mathrm{hr}$. was a slight decrease of the ${ }^{3} \mathrm{H} /{ }^{14} \mathrm{C}$ ratio observed, indicating that no more than $5 \%$ of the total radioactivity could have been due to the tritium-deficient substance. In contrast with this finding, in the nuclear-debris fraction peak $P$ material, consisting mainly of the ${ }^{3} \mathrm{H}$-deficient substance, rose rapidly in amount to $55 \%$ at $8 \mathrm{hr}$. and was still at this value at $16 \mathrm{hr}$. The dotted line shows tentatively the proportion of the ${ }^{3} \mathrm{H}$ deficient substance in the nuclear-debris fraction, 
Table 7. Chromatographic distribution of the radioactivity from the lipid extracts of various tissues after a dose of $\left[4-{ }^{14} \mathrm{C}, 1-{ }^{3} \mathrm{H}\right]$ cholecalciferol to vitamin $D$-supplemented birds

The extracts were prepared from vitamin D-supplemented chicks as described in Table 6. Results are expressed as percentages of the ${ }^{14} \mathrm{C}$ radioactivity recovered.

\begin{tabular}{|c|c|c|c|c|c|c|}
\hline \multirow[b]{2}{*}{ Chromatographic peak } & \multicolumn{2}{|c|}{ Liver } & \multicolumn{2}{|c|}{ Kidney } & \multicolumn{2}{|c|}{ Intestinal nuclear debris } \\
\hline & $\begin{array}{c}\text { Distribution } \\
\left(\% \text { of }{ }^{14} \mathrm{C}\right)\end{array}$ & $\begin{array}{c}{ }^{3} \mathrm{H} /{ }^{14} \mathrm{C} \\
\text { ratio }\end{array}$ & $\begin{array}{c}\text { Distribution } \\
\left(\% \text { of }{ }^{14} \mathrm{C}\right)\end{array}$ & $\begin{array}{c}{ }^{3} \mathrm{H} /{ }^{14} \mathrm{C} \\
\text { ratio }\end{array}$ & $\begin{array}{c}\text { Distribution } \\
\left(\% \text { of }{ }^{14} \mathrm{C}\right)\end{array}$ & $\begin{array}{c}{ }^{3} \mathrm{H} /{ }^{14} \mathrm{C} \\
\text { ratio }\end{array}$ \\
\hline Cholecalciferol ester & $10 \cdot 1$ & $3 \cdot 8$ & $7 \cdot 3$ & $4 \cdot 4$ & $0 \cdot 0$ & - \\
\hline Cholecalciferol & $83 \cdot 0$ & $3 \cdot 8$ & $84 \cdot 9$ & $3 \cdot 7$ & $89 \cdot 9$ & $3 \cdot 6$ \\
\hline 25-Hydroxycholecalciferol & $4 \cdot 7$ & $3 \cdot 4$ & $5 \cdot 6$ & $4 \cdot 4$ & $10 \cdot 1$ & - \\
\hline Peak $P$ & $2 \cdot 2$ & $3 \cdot 5$ & $3 \cdot 2$ & $2 \cdot 8$ & 0.0 & - \\
\hline
\end{tabular}
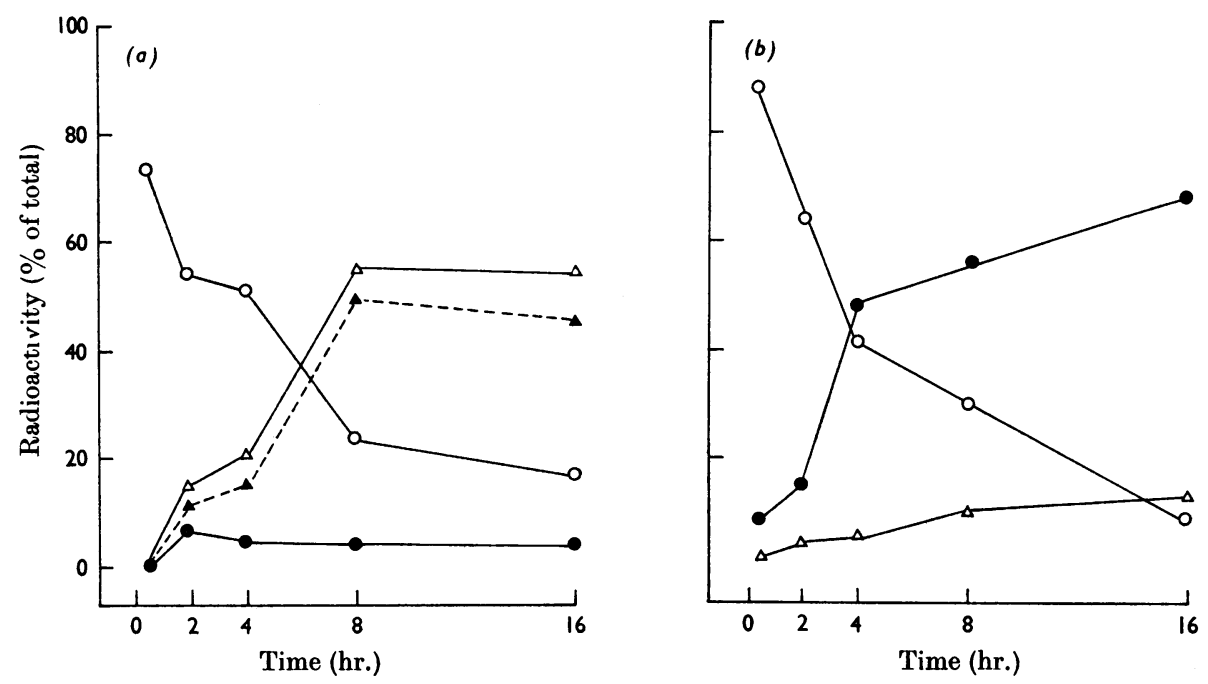

Fig. 3. Time-course of the appearance of radioactive components from lipid extracts of the intestinal nucleardebris fraction $(a)$ and of blood $(b)$ from vitamin $D$-deficient chicks after a $0.5 \mu \mathrm{g}$. dose of $\left[4-{ }^{14} \mathrm{C}, 1-{ }^{3} \mathrm{H}\right] \mathrm{cholecalciferol}$. ○, Cholecalciferol; $\bullet, 25$-hydroxycholecalciferol; $\triangle$, peak $\boldsymbol{P} ; \boldsymbol{\Delta},{ }^{3} \mathrm{H}$-deficient substance (for calculation see the text).

calculated from the ${ }^{3} \mathrm{H} /{ }^{14} \mathrm{C}$ ratios given previously (Lawson et al. 1969b).

The absence of peak $P$ material from tissues where cholecalciferol or 25-hydroxycholecalciferol was present and its absence from the intestine of the vitamin D-supplemented chicks shows that peak $P$ is not due to an artifact from these compounds formed, for example, by autoxidation. This was further shown by adding $\left[4-14 \mathrm{C}, 1{ }^{3} \mathrm{H}\right]$ cholecalciferol to an intestinal homogenate before extraction and chromatography of the lipids in the normal manner. There was no indication of any substance with a changed ${ }^{3} \mathrm{H} /{ }^{14} \mathrm{C}$ ratio in the area of the chromatogram at which peak $P$ is found.

Formation of peak $\mathrm{P}$ material from 25-hydroxycholecalciferol. Since the major radioactive com- ponent in blood after a dose of labelled vitamin is 25-hydroxycholecalciferol and since this metabolite has a longer half-life than cholecalciferol (Mawer \& Stanbury, 1968), it seemed likely that 25-hydroxycholecalciferol is the more immediate precursor of peak $\boldsymbol{P}$ material, or the ${ }^{3} \mathrm{H}$-deficient substance, or both. 25-Hydroxy[4-14 $\left.\mathrm{C}, 1-{ }^{3} \mathrm{H}\right]$ cholecalciferol was prepared and an equivalent of $0.4 \mu \mathrm{g}$. administered to each of two vitamin D-deficient chicks. The proportion of the ${ }^{14} \mathrm{C}$ dose recovered in the lipid extracts of the various tissues $8 \mathrm{hr}$. later ranged from $1.5 \% / \mathrm{ml}$. of blood to $0.1 \% / \mathrm{g}$. of fresh muscle and bone (Table 8). The adrenals did not contain any radioactivity. The lipid extracts were then chromatographed on silica gel with batch elution (Table 9). As with a dose of cholecalciferol, radio- 
activity was detected in the peak $P$ region of the chromatogram of the blood extract, but the ${ }^{3} \mathrm{H} /{ }^{14} \mathrm{C}$ ratio was unchanged. Similarly the small amount of adipose-tissue radioactivity in the peak $P$ region could not be attributed to the ${ }^{3} \mathrm{H}$-deficient substance.

Various amounts of peak $\boldsymbol{P}$ material were found in all other tissues examined, with the highest proportions and the lowest ${ }^{3} \mathrm{H} /{ }^{14} \mathrm{C}$ ratios in the intestinal fractions. A higher proportion of the radioactivity in the intestinal nuclear-debris fraction was due to the ${ }^{3} \mathbf{H}$-deficient substance in peak $P(77 \%)$ compared with that found after an equivalent dose of cholecalciferol $(50 \%)$.

25-Hydroxycholecalciferol accounted for the highest proportion of the radioactivity in all tisscies except the intestine. Although as much as $14 \%$ of the radioactivity in the liver was detected in the ester region of the chromatogram, we could not yet show that it was an ester of 25-hydroxycholecalciferol, cholecalciferol or the ${ }^{3} \mathrm{H}$-deficient substance. The lowered ${ }^{3} \mathrm{H} /{ }^{14} \mathrm{C}$ ratio might be of significance in this connexion.

Intranuclear distribution of $\left[4-14 \mathrm{C}, 1-{ }^{3} \mathrm{H}\right]$ cholecalciferol. Chromatin was prepared as described by Haussler et al. (1968) from the intestine of chicks dosed with 0.25 or $0.5 \mu \mathrm{g}$. of $\left[4-{ }^{14} \mathrm{C}, 1-{ }^{3} \mathrm{H}\right] \mathrm{chole}$ calciferol (Table 10). The recovery of chromatin was $85 \%$ and as expected there was very little ${ }^{3} \mathbf{H}$ radioactivity present, but $50 \%$ of the intestinal ${ }^{14} \mathrm{C}$ radioactivity was detected in the chromatin preparation. Chromatography of the chromatin lipid extracts gave a picture identical with that obtained from the nuclear lipids. Thus over $95 \%$ of the ${ }^{14} \mathrm{C}$ radioactivity was eluted in the peak $P$ area of the chromatogram. The ${ }^{3} \mathrm{H} /{ }^{14} \mathrm{C}$ ratio of this material was again very low, being less than 0.2:1.

In view of the findings by Stohs \& DeLuca (1967) that treatment of nuclei with Triton $X-100$ resulted in an almost complete loss of the nuclear radioactivity, which they correlated with the disruption of the outer nuclear membrane, we have investigated this effect (D. E. M. Lawson, P. W. Wilson \& E. Kodicek, unpublished work). We have been able to confirm the effect of $1 \%$ Triton X-100 on the external membrane, but some $20 \%$ of the nuclear radioactivity still remained with the damaged nuclei. It appears that, under our conditions, the effect of Triton X-100 was not confined to the outer membrane only, as electron-microscopic examination showed a severe effect on the chromatin in addition to the loss of the nuclear membranes.

As mentioned above it has been shown that a different qualitative pattern of metabolism of vitamin $D$ is obtained at doses up to $1 \mu \mathrm{g}$. compared with doses of, for example, $10 \mu \mathrm{g}$. We have investigated the effect of lowering the dose of both cholecalciferol and 25-hydroxycholecalciferol to as little as $0.025-0.05 \mu \mathrm{g}$. In general the pattern was no different from that obtained with $0 \cdot 25 \mu \mathrm{g}$. of cholecalciferol with the exception that the tissues retained a slightly higher proportion of the dose. The pattern and proportion of metabolites observed in liver, intestine and blood with these low doses was very similar to that seen at the $1 \mu \mathrm{g}$. level.

\section{DISCUSSION}

The availability of $\left[4-{ }^{14} \mathrm{C}\right]$ - and $\left[1 \alpha^{-3} \mathrm{H}\right]$-cholecalciferol has enabled us to detect a further metabolite of the vitamin and obtain some indications as to its structure. These conclusions have been obtained from results indicating a loss of hydrogen at C-1, but without loss of carbon at C-4 from the cholecalciferol molecule. Although several explanations can be given to account for the variation in the ${ }^{3} \mathrm{H} /{ }^{14} \mathrm{C}$ ratio of peak $P$ in the various chromatograms described above, the simplest of these, which we have chosen as a working hypothesis, is that there are two metabolites of cholecalciferol involved. Both of these metabolites are more polar than 25. hydroxycholecalciferol and seem to be formed from it. Comparison with the chromatographic properties of other steroids (van Lier \& Smith, 1967) suggests that the increased polarity is due to the insertion of another oxygen function into the cholecalciferol molecule in addition to the one at C-25. In fractions that show a ${ }^{3} \mathrm{H} /{ }^{14} \mathrm{C}$ ratio close to that of the original cholecalciferol, as seen for example in blood and adipose tissue, the oxygen function must be other

Table 8. Distribution of radioactivity in tissue lipid extracts after a dose of $25-h y d r o x y\left[4-{ }^{14} \mathrm{C}, 1-{ }^{3} \mathrm{H}\right]-$ cholecalciferol

Vitamin D-deficient birds were each given a $0 \cdot 4 \mu \mathrm{g}$. dose of 25 -hydroxy $\left[4-{ }^{14} \mathrm{C}, 1-{ }^{3} \mathrm{H}\right]$ cholecalciferol $\left({ }^{3} \mathrm{H} /{ }^{14} \mathrm{C}\right.$ ratio $4 \cdot 4: 1$ ) and killed after $8 \mathrm{hr}$. Results are expressed as percentages of the dose/g. of fresh tissue, and for intestinal fractions/g. of original mucosa.

\begin{tabular}{|c|c|c|c|c|c|c|c|c|c|}
\hline & Blood & Liver & Kidney & $\begin{array}{c}\text { Intestinal } \\
\text { supernatant } \\
\text { fraction }\end{array}$ & $\begin{array}{c}\text { Intestinal } \\
\text { nuclear } \\
\text { debris }\end{array}$ & Heart & Muscle & $\begin{array}{c}\text { Tibial } \\
\text { epiphyses }\end{array}$ & $\begin{array}{c}\text { Adipose } \\
\text { tissue }\end{array}$ \\
\hline Distribution & & & & & & & & & \\
\hline$\left(\%\right.$ of $\left.{ }^{14} \mathrm{C}\right)$ & $1 \cdot 5$ & $0 \cdot 18$ & $0 \cdot 18$ & $0 \cdot 15$ & $0 \cdot 19$ & $0 \cdot 19$ & $0 \cdot 10$ & $0 \cdot 11$ & $0 \cdot 28$ \\
\hline$\left(\%\right.$ of $\left.{ }^{3} \mathrm{H}\right)$ & $1 \cdot 3$ & $0 \cdot 15$ & $0 \cdot 11$ & $0 \cdot 05$ & $0 \cdot 01$ & $0 \cdot 17$ & $0 \cdot 07$ & $0 \cdot 10$ & $0 \cdot 28$ \\
\hline
\end{tabular}


Table 10. Radioactivity in the chromatin fraction from intestinal mucosa after $a$ dose of $\left[4-{ }^{14} \mathrm{C}, 1-{ }^{3} \mathrm{H}\right]-$ cholecalciferol

Vitamin D-deficient chicks were dosed with doublelabelled cholecalciferol and chromatin fractions were prepared from their intestinal mucosa $16 \mathrm{hr}$. later. Results are expressed as percentages of the dose in the chromatin corrected for the recovery of DNA.

\begin{tabular}{|c|c|c|}
\hline \multirow[b]{2}{*}{ Dose ( $\mu$ g.) } & \multicolumn{2}{|c|}{ Distribution } \\
\hline & $\left(\%\right.$ of $\left.{ }^{14} \mathrm{C}\right)$ & $\left(\%\right.$ of $\left.{ }^{3} \mathrm{H}\right)$ \\
\hline 0.5 & 0.52 & 0.05 \\
\hline $0 \cdot 25$ & 0.42 & 0.06 \\
\hline
\end{tabular}

than at C-1 or vicinal carbon atoms. The decrease in the ${ }^{3} \mathrm{H} /{ }^{14} \mathrm{C}$ ratio could be brought about by the involvement of the ${ }^{3} \mathrm{H}$ at $\mathrm{C}-1$ in the insertion of the second oxygen function into either C-1 or via an epoxide into C-10 of the cholecalciferol molecule. Another possibility that can be considered would be a loss of ${ }^{3} \mathrm{H}$ by a shift of double bonds due to isomerization of vitamin $\mathrm{D}$ and insertion of an oxygen function in a region of the molecule remote from C-1. The variation in the ratio in tissues could therefore be due to the presence of various amounts of the blood metabolite that has not lost ${ }^{3} \mathrm{H}$. The intestine contains the highest proportion of the ${ }^{3} \mathrm{H}$-deficient substance, and the intestinal nuclei appear to derive their radioactivity almost entirely $(97 \%)$ from the presence of the ${ }^{3} \mathrm{H}$ deficient substance.

The isolation and analysis of this compound is difficult since the binding capacity of the intestinal cell receptors for this substance is finite. Thus we have not been able to raise its concentration above lng./g. of tissue. Further, we have not been able to detect with certainty the ${ }^{3} \mathrm{H}$-deficient substance in vitamin D-supplemented chicks.

The biological significance of this ${ }^{3} \mathrm{H}$-deficient metabolite has yet to be evaluated. The finding that $8 \mathrm{hr}$. after a dose of labelled cholecalciferol or 25 hydroxycholecalciferol the ${ }^{3} \mathrm{H}$-deficient substance accounts for most of the radioactivity in the intestine supports the view that it is of importance in understanding the function of vitamin $D$. In preliminary experiments it was also found in pig intestinal cells. The final proof of this will be the demonstration of its biological activity, but this must await the availability of this substance in sufficient quantity.

As mentioned above it has been shown (Haussler et al. 1968) that a chromatographic fraction of chick intestine, originally called Peak IV (Norman et al. 1964), consists of at least three components, designated $4 \mathrm{a}, 4 \mathrm{~b}$ and $4 \mathrm{c}$. In the whole intestine component $4 \mathrm{~b}$ was the major component and was 
localized on the chromatin. Although 25-hydroxycholecalciferol is a component of Peak IV (Blunt et al. 1968), Haussler et al. (1968) were unable to state which of these three substances was 25-hydroxycholecalciferol. It was shown that both component $4 \mathrm{a}$ and component $4 \mathrm{~b}$ had biological activity, but an unconventional method of assay had to be used owing to the small amount of material available. Comparison of the chromatographic procedure of Haussler et al. (1968) with that used by us suggests that component $4 \mathrm{a}$ is 25 -hydroxycholecalciferol and that component $4 \mathrm{~b}$ corresponds to our peak $P$. However, these authors stated that there is no loss of ${ }^{3} \mathrm{H}$ from their preparation of labelled chole. calciferol in the formation of component $4 \mathrm{~b}$.

The binding of all the nuclear ${ }^{3} \mathrm{H}$-deficient substance to the chromatin offers a possible explanation of the stimulation by vitamin $D$ of the incorporation of $\left[5-{ }^{3} \mathrm{H}\right]$ orotic acid into RNA (Norman, 1966; Stohs, Zull \& DeLuca, 1967; Lawson et al. 1969a). This stimulation did not involve an increase in either the RNA polymerase activity or the pool size of the RNA or its precursors (Lawson et al. 1969a). It is possible that vitamin D functions by affecting the template capacity of the chromatin, as already shown for oestradiol (Barker \& Warren, 1966), possibly as an allosteric factor.

We are grateful to Dr M. E. Coates, National Institute for Research in Dairying, Shinfield, Reading, for the supply of 1-day-old chicks. We thank Miss A. C. Ludlow for skilled technical assistance.

\section{REFERENCES}

Barker, K. L. \& Warren, J. C. (1966). Proc. nat. Acad. Sci., Wash., 56, 1298.

Bell, P. A. \& Kodicek, E. (1967). Biochem. J. 105, 34 P.

Bligh, E. G. \& Dyer, W. J. (1959). Canad. J. Biochem. Physiol. 37, 911.
Blunt, J. W., DeLuca, H. F. \& Schnoes, H. K. (1968). Biochemistry, 7, 3317.

Blunt, J. W., Tanaka, Y. \& DeLuca, H. F. (1968). Prcc. nat. Acad.Sci., Wash., 61, 717.

Callow, R. K., Kodicek, E. \& Thompson, G. (1966). Proc. Roy. Soc. B, 164, 1.

Fraser, D. R. \& Kodicek, E. (1965). Biochem. J. 96, 59 P.

Fraser, D. R. \& Kodicek, E. (1966). Biochem. J. 100, 67 P.

Fraser, D. R. \& Kodicek, E. (1968). Biochem. J. 106, 491.

Fraser, D. R. \& Kodicek, E. (1969). Brit. J. Nutr. 23, 135.

Haussler, M. R., Myrtle, J. F. \& Norman, A. W. (1968). J. biol. Chem. 243, 4055.

Haussler, M. R. \& Norman, A. W. (1967). Arch. Biochem. Biophys. 118, 145.

Kodicek, E. (1955). Biochem.J. 60, xxv.

Kodicek, E. (1963). In Transfer of Calcium and Strontium Across Biological Membranes, p. 185. Ed. by Wasserman, R. H. New York: Academic Press Inc.

Lawson, D. E. M., Wilson, P. W., Barker, D. C. \& Kodicek, E. $(1969 a)$. Biochem. J. 115, 263.

Lawson, D. E. M., Wilson, P. W. \& Kodicek, E. (1969b). Nature, Lond., 222, 171.

Mawer, E. B. \& Stanbury, S. W. (1968). Biochem. J. 110, $53 \mathrm{P}$.

Neville, P. F. \& DeLuca, H. F. (1966). Biochemistry, 5, 2201.

Norman, A. W. (1966). Biochem. biophys. Res. Commun. 23, 335.

Norman, A. W. \& DeLuca, H. F. (1963). Biochemistry, 2, 1160.

Norman, A. W. \& DeLuca, H. F. (1964). Arch. Biochem. Biophys. 107, 69.

Norman, A. W., Lund, J. E. \& DeLuca, H. F. (1964). Arch. Biochem. Biophys. 108, 12.

Schneider, W. C. \& Hogeboom, G. H. (1950). J. biol. Chem. $183,123$.

Stohs, S. J. \& DeLuca, H. F. (1967). Biochemistry, 6, 3338.

Stohs, S. J., Zull, J. E. \& DeLuca, H. F. (1967). Biochemistry, 6, 1304.

van Lier, J. E. \& Smith, L. L. (1967). Biochemistry, 6, 3269.

Wilson, P. W., Lawson, D. E. M. \& Kodicek, E. (1967). Biochem. J. 108, 165. 